\title{
Protein Delta Homolog 1
}

National Cancer Institute

\section{Source}

National Cancer Institute. Protein Delta Homolog 1. NCI Thesaurus. Code C99662.

Protein delta homolog 1 (383 aa, $41 \mathrm{kDa}$ ) is encoded by the human DLK1 gene. This protein plays a role in intercellular communication. 